\title{
TAX SALES AND FORECLOSURES UNDER THE MODEL TAX COLLECTION LAW
}

\author{
HENRY Brandis, JR.*
}

This article is concerned only with a very brief examination of the sale and foreclosure provisions of the so-called Model Real Property Tax Collection Law ${ }^{1}$ drafted by a special committee of the National Municipal League under the chairmanship of Mr. Arnold Frye of the New York Bar. The first twenty sections of the Law, which deal with collection procedure prior to sale, and which contain a number of provisions calculated to aid or insure efficient collection, are beyond the scope of the article.

For introductory purposes the sale and foreclosure provisions of the Law may be summarized as follows: After due advertisement by posting and publication, a sale of liens for delinquent real property taxes is to be held on October first following the fiscal year in which the liens attach. All liens held by different taxing districts against the same parcel are to be consolidated for purposes of this sale, and one district is to be charged by law with duty of enforcement. A tax sale certificate, representing the liens against the parcel, is to be issued to the bidder who will accept the lowest interest rate, the maximum allowable rate being $12 \%$ per annum. If there are no bids within this maximum the taxing district becomes the purchaser at an interest rate of $10 \%$ per annum. Failure to sell at the proper time does not affect the lien, but if the sale is not held within three months of the prescribed time the office of the collector is automatically vacated and the sale is to be conducted by the State Tax Commissioner (or-similar official). In the case of liens amounting to less than ten dollars the sale may be deferred, in the collector's discretion, until the third October first following the close of the fiscal year.

The purchaser of the certificate may record it and if such purchaser is not a taxing district failure to record within three months after the sale renders the certificate void as to bona fide purchasers, lessees and mortgagees first recording their interests.

- A.B., 1928, University of North Carolina; LL.B., 1931, Columbia University. Member of the New York and North Carolina Bars. Associate Director of The Institute of Government, Chapel Hill, N. C. Instructor in Tax Administration, University of North Carolina. Author of Collection and Foreclosture of County and City Property Taxes in North Carolina (Institute of Government, 1935); Listing and Assessing of Property for County and City Taxes in North Carolina (Institute of Government, 1936). Contributor to legal periodicals.

I The full text of the Model Law will be found printed as a supplement to the May, 1935, issue of the National Municipal Review. 24 Nat. MuN. REv. 290. 
The certificate is made "presumptive evidence" of the truth of its statements, title to the property, and the validity of the prior proceedings. This presumption so created becomes conclusive two years from the date of recordation.

Redemption may be had by payment of the face amount of the certificate plus interest, subsequent municipal charges and taxes, and such expenses as may have been incurred and properly proved by the certificate holder, such expenses not to exceed twelve dollars. All redemption payments are to be made to the collector for the use of the purchaser.

The certificate holder, whether private person or taxing district, may bring a foreclosure action: (a) after one year from date of sale, or (b) after default in any semi-annual interest instalment, or (c) after default in payment of any subsequent municipal tax or charge. When a taxing district holds a certificate it may allow redemption not only by a lump sum payment but also by instalments covering a period not exceeding five years, and once such an arrangement has been made the district may not assign the certificate or begin foreclosure until after default on an instalment or default on payment of some subsequent tax or municipal charge. The foreclosure action may take the form of an action in personam or an action in rem at the option of the certificate holder. In the latter type of action the only service of process required is publication and posting of a prescribed notice to the persons interested in the property, who need not be named; a lis pendens is also to be filed.

In neither type of action is it contemplated that there will be a judicial sale of the property. The judgment will take the form of a declaration that the plaintiff is the owner of the property in fee. Certificates owned by the same plaintiff, though affecting different parcels, may be joined in one action. Except when brought by a taxing district no foreclosure action may be concluded by judgment until all subsequent municipal charges and taxes have been paid.

At the outset, it should be remarked that, in selecting the device of judicial foreclosure of the tax lien in lieu of the execution of a deed to the tax certificate holder by an administrative official, the draftsmen of the Model Law have adopted, in the interest of security of tax titles, a procedure which has been criticized as clumsy and expensive. However, the foreclosure proceeding in rem for which the Law makes provision is stripped of those requirements which are a principal source of expense and delay to the foreclosing lienholder. By rendering it unnecessary that persons having an interest in the property be named in the published summons, thie need for a costly title search to ascertain their identity is obviated. The provision that actions against different parcels may be consolidated represents another saving. A third economy results from the elimination of the necessity for a public sale of the property in the foreclosure proceeding. It is perhaps not too much to say that the principal difference between foreclosure in rem under the Model Law and the administrative procedure for conveyance as it exists in a number of states is that the former takes place in the court-room and the latter in the sheriff's office. 
With the desirability and soundness of the general purposes of the Law the writer is in agreement, and with the majority of its provisions there can be little quarrel. Consequently no useful purpose could be served by an attempt (particularly by this writer) to weigh each section and approve or disapprove its provisions. The writer desires only to discuss briefly a few provisions with respect to which there may be room for modification or improvement or at least for a difference of opinion. Upon the questions he raises he does not pretend to pose as the ultimate oracle. He freely concedes that he is outnumbered and outranked by the League's committee in both wisdom and experience. Further, he is the first to concede that his approach to the problems may be too narrowly confined by the range of his experience, which consists largely in the study of the operation of the sale and foreclosure laws of North Carolina during the years of depression and incipient recovery-laws which, as interpreted by our courts, could under no circumstances be called model. His reason for raising these questions is his belief that they are legitimate matters for legislative attention in states comparable to North Carolina, which itself is-or ought to bein the market for a new foreclosure law.

Professor Roger J. Traynor, in a recent issue of the California Law Review, ${ }^{2}$ has made a number of suggestions with respect to the Model Law with which the writer, in the main, is in agreement. It is not necessary to examine all these suggestions here, and only those in connection with the matter of recording tax certificates will be discussed herein. ${ }^{3}$ For convenience in presentation the questions the writer wishes to raise will be divided numerically and more or less arbitrarily, and no attempt will be made to present any summarizing conclusions:

(I) When the taxing district becomes the purchaser, why issue a tax sale certificate? It has been the observation of the writer that when collection records are otherwise adequate the issue of certificates to the taxing unit serves more to confuse than to aid the record system. The "sale" can be held in the manner proposed by the Law and the taxing district can be given the same rights after sale that the Law proposes; but can anything be accomplished by giving to the unit a separate piece of paper called a "certificate" that cannot be accomplished by the preservation of the

2 (I935) 24 Carif. L. Rev. 98.

The principal points made by Professor Traynor with respect to provisions of the Law discussed in this article are the following:

(I) The relationship between the three remedies accorded the taxing unit, personal action as for a debt, receivership proceedings, and the sale of tax certificates, should be clarified by a provision stating these remedies to be cumulative. Id. at roz.

(2) The provision that the certificate of sale should be "presumptive evidence" of the truth of the statements therein should be strengthened by substituting "prima facie" for "presumptive," and this presumption should be rendered conclusive two years from the date of the issuance of the certificate rather than from the date of its recordation. Id. at ro3.

(3) The differentiation in the Law between foreclosure proceedings in personam and in rem seems unnecessary since evidently under neither is sale of the property or a deficiency judgment contemplated. "A simple provision" for "either personal service or service by publication at the option of the holder" mould suffice. Id. at 104. 
predetermined tax receipt or at most by giving such a receipt a brief lick with a rubber stamp?

It is true that the Model Law hopes to place tax liens in the hands of independent purchasers, but this cannot be done in every case. If the experience of North Carolina during the past few years means anything it means that we will have no substantial revival of independent buying of certificates during the next few years, with or without the Model Law. In one of our counties more than 15,000 certificates were issued to taxing districts in one year, despite the fact that in the particular county the collection offices of city and county have been consolidated. The time and expense involved in this, which are considerable, represent almost a complete waste. A collector in one of our larger cities has saved his city considerable sums over a period of years by refusing (in violation of the law) to issue certificates in the name of the city until the City Attorney demands them for foreclosure purposes, by which time the majority of the liens have been paid.

Perhaps this suggestion might seem trivial and purely formal; but in North Carolina alone the total saving involved would be extremely worthwhile, and it is certain that North Carolina is not the only state in which private purchasing of certificates is so rare as to be virtually nonexistent. ${ }^{4}$ Because all record systems might not be equally suited to adoption of this suggestion, it would probably be best to give to local authorities the privilege of eliminating issue of certificates to taxing districts wherever it would not result in impairment of the efficiency of the collection records.

In a few cases it is possible that the predetermined tax receipts could easily be converted into certificates even when there is a private purchaser.

(2) Is the method of selling on the basis of the lowest interest rate bid the best method of selling which can be devised? Of course, if there are no bidders at sales or if there are only a few bidders at the maximum rate this question is unimportant; but the Model Law is based on the assumption that in normal times there will be a substantial number of competitive bidders, and it is in the light of this assumption that the provision must be discussed.

It is a political axiom.in this neck of the woods that "you ought to feed everybody out of the same spoon." It is no doubt true that this classically colloquial phrase has been the constant cry of demagogues, and by this association its social and intellectual standing has suffered. But if the demagogues have been attracted by its effectiveness, the people have been attracted by its essential wisdom. Only in the manner of its application is there real room for argument.

It is true that you can and ought to discriminate between the man who pays his taxes promptly and the man who delays his payment. However, is it wise to provide deliberately for a difference in treatment for two taxpayers who, in point of time, are equally delinquent? Whether the interest rates proposed by the Model Law

\footnotetext{
'See Upson, Tax Delinquency: Administration and Legislation, I934 PRoc. NAT. TAx Ass'N 356; 362 363; Wager, The Reversion of Tax Delinquent Lands, id. 367, 368, 369; discussion by Simeon E. Leland, 1935 id. 267.
} 
are too high or too low is not a question now being raised. The only question is whether or not there is potential unwarranted discrimination in the competitive interest rate bidding. That there is at least a potential difference in treatment can hardly be denied.

The majoriy of the League's committee frankly approve this difference in treatment. Its chairman has said that this is the form of sale "universally approved." He has also said: "Competition on the basis of the interest rate, however, seems to have been productive of the best results, both from the standpoint of the taxpayer and the taxing district." The writer has known numerous delinquent taxpayers who would accept this conclusion only at the point of a pistol and then only with such mental reservations as any man is allowed under such circumstances.

Wherever delinquency is common enough to be a political issue, as it has been and still is in many places, taxpayers will object vociferously if they have to pay $10 \%$ or $12 \%$ when their equally delinquent neighbors are paying $6 \%$ or $8 \%$. Can it be said, because a taxpayer owns a less desirable or less productive property than his neighbor, that he has no legitimate reason to protest such a situation? Of course, the law does not carry out the principle of reducing interest in proportion to desirability of risk with complete logic, because, while some mediocre risks may be purchased by private bidders at $12 \%$, the worst risks will fall to the taxing districts at $10 \%$. But, in its broadest aspects, the Model Law is designed to graduate the interest rate in accordance with desirability of the risk.

This type of competition may well serve to accentuate any disadvantages or discrimination already present in the property tax system or in the valuations placed on individual properties. If a parcel has been mistakenly overvalued by comparison to neighboring property, then its owner, if his taxes become delinquent, will probably pay a higher rate of interest than his equally delinquent neighbors. If a parcel is vacant the owner will probably pay a higher rate of interest than the equally delinquent owners of improved properties. Obviously, instead of attempting to mitigate hardships. and inequalities in our system we are simply making them more apparent and unjust.

It seems at least arguable that, where popular psychology is ripe for such doctrine, the taxpayer who claims that he is being fed from a different spoon will have enough of truth behind him to enable him to make trouble. Further, it seems at least arguable that even if he cannot cause serious trouble, his cause is yet sound enough to entitle him to consideration. A possible alternative to the Model Law provision is sale to the highest bidder, with the surplus over the tax liens reverting to the owner, with a fixed rate of interest applying to the amount of the liens and a much lower rate of interest applying to the surplus amount. In effect the bidders will still

- Frye, Tax Delinquency and Tax Collection, an address delivered before the University of Virginia Institute of Public Affairs, July 9, 1935. 
bid on a yield basis, while the taxpayers will be accorded much more equal treatment than they would be accorded under the Model Law. ${ }^{6}$

Another possible alternative would be the sale at a fixed rate of interest to the first person who will bid the amount of the liens. This, of course, would have the virtue of placing all taxpayers on an identical basis, though concededly it might result in some confusion and favoritism, and would destroy any vestige of competitive bidding, which still seems to be regarded as desirable by most authorities. ${ }^{7}$

(3) Will the provision allowing the sale to be postponed from the first to the third October in cases where the liens amount to less than \$10, result where followed in positive encouragement to delinquency on the part of small land owners? Obviously it is difficult to give a definite and final answer which will fit all cases. It is probably desirable, from the practical standpoint, to allow some leeway in the matter of foreclosure of small tax liens, so that the cost of foreclosure will not be disproportionate to the amount of the lien. However, it does not seem altogether certain that the method proposed by the Model Law is the most desirable method.

The tax sale itself is comparatively inexpensive, particularly if, as suggested by the writer, the cost of issuing a certificate can be eliminated at least in cases where the taxing unit is purchaser. The Model Law places no statute of limitations on the right to foreclose; nor does it require that all certificates held by a taxing unit for the same year must be foreclosed at the same time. Therefore, there is nothing to prevent the certificate holder (which in most cases of small liens will be the taxing district) from allowing several years' taxes to accumulate before bringing foreclosure actions. Would not this serve the same purpose as the proposed provision allowing waiver of sale? If so, it would have the very definite advantage of allowing the matter to be handled by a quietly effected policy, whereas under the waiver of sale method it would immediately be apparent that small liens were not being sold. This should at least minimize the possibility of encouraging delinquency on small items.

Either the Model Law provision or the suggested alternative may involve discrimination, though because it would work in favor of small taxpayers there seems little likelihood that such discrimination would cause serious trouble. However, even if the principle of the Model Law provisions is retained, many units having a preponderance of small taxpayers may desire to have the amount reduced to something less than \$ro.

(4) Is it wise to incorporate all liens against the same property in the same certificate? It appears from the footnotes appended to the draft of the Model Law

\footnotetext{
- From 2 footnote to section 27 of the Model Law, it appears that one member of the committee favored sale to the highest bidder as distinguished from bidding on the interest rate. (1935) 24 NAT. Mun. Rev. (Supp.) at 299.

'In practice in North Carolina in the last few years, such few private bids as have come to the attention of the writer seem to have been made on this basis, though the statute nominally calls for sale to the highest bidder. See N. C. Cone (Michie, I935) \$8015. However, sale to the person who will bid the amount due has been the law in at least six states. See Wager, supra note 4 , at 367 .
} 
that the committee may hope that the provisions to this effect will encourage consolidation of tax collection functions, but may not necessarily intend that all liens shall be consolidated for certificate purposes when there is no other consolidation of collection functions. ${ }^{8}$ If such is the case, the writer is in thorough accord with the general purpose. Further, he is in accord with the idea that all collection functions should be consolidated. However, when primary collection functions have not been consolidated, there may be numerous individual situations in which an attempt to consolidate the liens for sale purposes will lead to great confusion. Of course, foreclosures could be jointly conducted even though liens are not consolidated for certificate purposes. In the absence of a state-wide law consolidating general collection it seems somewhat doubtful that this could be handled adequately on a statewide basis: Perhaps the pressure for this partial consolidation is not as great in North Carolina as in some other states, as in this state in most places counties and cities are now virtually the only agencies collecting real property taxes.

(5) Should there be some form of statute of limitations on the right to foreclose? This question can probably be answered in the negative so far as independent purchasers are concerned. The taxing unit has received its money from them and they can be relied upon to protect their own rights. The possibility that they may foreclose at some time other than that selected by the unit is already inherent in the Model Law, and whatever discrimination may be involved in this possibility is not increased by the ensuing suggestions.

It seems to the writer that some form of statute of limitations is desirable with respect to foreclosures to be brought by taxing districts. The primary purpose of the Model Law is to insure a maximum of collection in a reasonable minimum of time. Attention has already been called to the provisions designed to require prompt sale of certificates by providing for removal of the tax collector from office upon failure to sell within three months of the prescribed time. Yet there is no provision which attempts to insure that the district will foreclose within a reasonable length of time. The only provision which might encourage reasonably prompt foreclosure is that which provides that if a taxing district holds a certificate for two years without beginning foreclosure it must pay the liens of other taxing districts on the same property. However, this would not operate where no other taxing districts are involved. Further, such purchasing district must also pay off the liens if it holds the property for one year after foreclosure, so that the effect of this provision, even if foreclosures are started, would be to encourage the plaintiff district to leave the action pending, without taking judgment, in order to escape the necessity of paying these liens.

Experience, at least in North Carolina, has shown that certificate sales have been delayed throughout the state by statute, by action of local authorities, and in a few cases by injunction. However, while sales have usually been delayed for a few months, foreclosures have been delayed for years. These delays in foreclosure have

\footnotetext{
"Soe footoote to section 22 of the Law. (1935) 24 Nar. Muv. Rev. (Supp.) at 298.
} 
developed despite the fact that North Carolina has a two-year statute of limitations, of the ordinary sort, on the most commonly used type of foreclosure. In fact, the exact status of taxes represented by many old tax certificates is now somewhat problematical.

It may be argued from this experience that a statute of limitations is so ineffective as to be undesirable in a tax foreclosure law. However, it is the opinion of the writer that the North Carolina statute is of the wrong type. Further, it is the opinion of most municipal attorneys in the state that an alternative type of foreclosure is still available in North Carolina and that there is no statute of limitations on it. In the writer's opinion the North Carolina experience proves nothing except that it is ineffective, during years of depression, to place an ordinary statute of limitations on tax foreclosures brought by taxing units. However, the Model Law contains a very salutary type of statute of limitations with respect to tax sales; and the same type of provision might well be extended to foreclosures. For instance, two years after sale might well be fixed as the time for beginning actions, and officials charged with the duty of bringing them might be removed from office for failure to bring them within three months after that time. Indeed, some further provision is probably needed to insure that actions, once brought, will be carried to a final conclusion with reasonable diligence.

Promptness in selling certificates, while having its effect, can never accomplish the desired results if foreclosures are never to be brought or are to be delayed for many years. The preliminaries will be excellent, but the main bout will not be held. In North Carolina, at least, the most drastic concessions made in recent years to delinquent taxpayers have been necessitated not primarily because of delayed sales but primarily because of accumulated delinquencies resulting from delayed foreclosures. ${ }^{9}$

In connection with such a limitation on foreclosure actions as has been suggested it would be necessary to consider, of course, the disposition to be made of the Model Law provisions dealing with small tax liens and dealing with instalment payment of certificates held by the taxing unit. Perhaps it might be desirable to make the limitation three years and eliminate both of these other provisions. However, the three ideas might be satisfactorily adjusted in a variety of ways.

(6) Should there be a sale of the property in the foreclosure proceedings? As already pointed out, both types of foreclosure actions provided by the Model Law culminate in judgment declaring the plaintiff to be owner of the property in fee. In neither case is there a provision for sale; apparently it is thought that the sale of the certificate is sufficient when coupled with the redemption provisions. It seems probable that in the majority of cases going to foreclosure judgment (the property being subject to redemption at any time before final judgment) the expense of advertising and holding a sale would be expense wasted on pure formality. How-

- See N. C. Public Laws 1933, c. r8x. This statute, together with statutes making concessions in a number of other states, is discussed in St. John, Real Property Tax Collection Procedure (June, I936) I4 TAx Magaztas 326. Unfortunately, the article contains several inaccuracies with respect to North Carolina. 
ever, within the writer's experience, even during the depression, there have been a few sales in tax foreclosure actions in which the bid was high enough to pay off tax liens and leave something additional for the former owner or other lien holders.

Perhaps all laws should be drawn with the average rather than the exceptional situation in mind. However, it is often easy to insert a provision which does no harm in the average case and provides appropriate treatment for the exceptional case. There will certainly be some cases in which a sale will be desirable or even necessary for fair settlement of the rights of the parties. Would not a reasonable solution be to allow any person having an interest in the property to demand a sale provided only that he guarantee the cost of sale? It is difficult to see how this could prejudice the rights of the plaintiff, whether the plaintiff be a private person or the taxing district; and the exceptional case would thereby be assured the necessary exceptional treatment.

(7) As already mentioned, the Model Law provides that if a taxing district holds a certificate for two years without foreclosing or if, after foreclosing, it holds the property for one year, it shall pay the taxes and charges of all other taxing districts on the same property. Does this provision need clarification? What happens if, within one year after foreclosure, the purchasing district decides that it will be advantageous to sell the property for less than the total of all liens accumulated? What happens when the district holds the certificate for more than two years under an instalment agreement made with the taxpayer? If within a year after foreclosure the purchasing district can find no buyer for the property, is it wise to require it to pay all other liens when it probably has no desire to hold the property?

In view of these questions and others that might be raised, would it not be more desirable to provide simply that the various interested units can negotiate an agreement with respect to the disposition of their various liens? While perhaps the present form of the Law would not prevent such agreements it would certainly discourage them, as other districts would be inclined to refuse to negotiate, secure in the knowledge that sooner or later the purchasing district would have to pay. The effect, wherever the various districts are not coextensive, would be, to sorne extent, a taxation of the land owners in one district for the benefit of the land owners in another, which seems rather doubtful policy.

A further consideration is injected into the question in states like North Carolina, in which, while county and city taxes are on a parity, special assessments are junior to both. ${ }^{10}$ Would the effect of the Law be to require a purchasing county to pay off city assessments which would otherwise be junior to its own taxes?

Finally, as already pointed out, the practical result of the provision, in some cases, might be to induce units to leave foreclosure actions pending indefinitely in order to escape the necessity of paying off liens held by other districts; and during this period the situation would simply become more and more complex.

(8) Is it necessary to require that the certificate be recorded? This is one of the

\footnotetext{
"Town of Saluda v. Polk County, 207 N. C. 180,176 S. E. 298 (1934).
} 
provisions which Professor Traynor discusses. He says that "the collector's records should show the existence of the lien and constitute sufficient notice to all persons dealing with the delinquent owner. .... It would seem no more necessary for the purchaser to record the certificate than for the municipality to record the levy of the tax."11

The sense of this comment is strengthened by the fact that under the Model Law all redemption payments are made directly to the collector even though the certificate is in private hands. There is, of course, much to be said for a concentration in one office of the records of all liens on real property. However, the necessity of consulting the tax records when searching title cannot be completely eliminated; and particularly is this true under the Model Law, as under its provisions taxing districts purchasing certificates, as distinguished from private bidders, would be under no necessity of recording them and the collector's records would have to be searched in any case.

One other consideration enters into the writer's opinion in this matter. North Carolina has, at present, a law which requires that a record of all tax certificates sold shall be filed in the office of the Register of Deeds, and that upon payment of the certificate it may be cancelled on the Register's records for a fee of ten cents. There is no charge for the original recording, which is not done by the purchaser but by means of a complete record of sales compiled by the collector in a special book which is then filed with the Register. ${ }^{12}$ A few of our units still obey this law scrupulously, probably because they fear the effects of failure to do so on subsequently acquired foreclosure titles. However, in the majority of the cases in which the writer has made any investigation of the practice, either the certificate record has never been filed or the filing has been discontinued. In cases in which the record has been filed the entry is seldom, if ever, cancelled upon payment; and lawyers searching title seem to pay little attention to the existence of the record. It is this consistent refusal to secure cancellations and the small attention paid the record by those interested in titles which have led many collectors to discontinue filing the record, which is not only troublesome but involves considerable expense to the taxing unit. It is impossible to say what effect failure to file has on tax titles, as our courts have not been called upon to pass on the point (an indication in itself as to how the matter is generally regarded). However, it can be said very definitely that, as a practical as distinguished from a technical matter, failure to file such a record has not damaged the taxing unit, the taxpayer, the certificate holder or those dealing with the taxpayer.

Of course, the provisions of the Model Law are in many respects not comparable to this North Carolina statute. However, North Carolina's experience seems to show that some types of recording, at least, are an unnecessary and often futile part of the collection process. There is sufficient similarity between the two provisions to cast considerable doubt on the necessity for the Model Law proposal.

${ }^{11}$ See Traynor, supre note 2, at ro3.

${ }^{12}$ N. C. Cope (Michie, 1935) 58017. 